\title{
Disruptive TP53 Mutation
}

National Cancer Institute

\section{Source}

National Cancer Institute. Disruptive TP53 Mutation. NCI Thesaurus. Code C125888.

Any mutation of the TP53 gene that results in a nonconservative mutation within the key

DNA-binding domain (L2-L3 region) of the p53 protein, or a stop codon in any region. 